Sains Malaysiana 47(5)(2018): 871-882

http://dx.doi.org/10.17576/jsm-2018-4705-02

\title{
Distribution of Polycyclic Aromatic Hydrocarbons (PAHs) in Surface Sediments of Langkawi Island, Malaysia
}

(Taburan Hidrokarbon Aromatik Polisiklik (HAP) dalam Permukaan Sedimen di Pulau Langkawi, Malaysia)

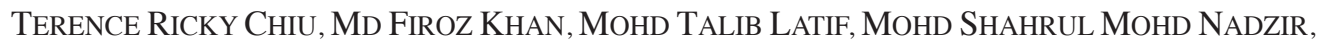 \\ HARIS HAFIZAL ABDUl HAMID, HAFIDZ YUSOFF \& MASNI MOHD ALI*
}

\begin{abstract}
The individual compounds and sources of polycyclic aromatic hydrocarbon (PAHs) were studied in the surface sediments at 32 locations in the tourism area of Langkawi Island. A total of 15 PAHs were determined and quantified by gas chromatography coupled with mass spectrometry (GC-MS). The total PAH concentrations of surface sediments from Langkawi Island ranged from 228.13 to $990.25 \mathrm{ng} / \mathrm{g}$ and they were classified as being in the low to moderate pollution range. All sampling stations were dominated by high molecular weight PAHs with 4 rings (31.59\%) and 5-6 rings (42.73\%). The diagnostic ratio results showed that in most cases, the sampling stations have pyrogenic input. Further analysis using principal component analysis (PCA) combined with absolute principal component score (APCS) and multiple linear regression (MLR) showed that the natural gas emissions contributed to $57 \%$ of the total PAH concentration, $22 \%$ from the incomplete combustion and pyrolysis of fuel, $15 \%$ from pyrogenic and petrogenic sources and $6 \%$ from an undefined source.
\end{abstract}

Keywords: APCS; diagnostic ratio; MLR; PAHs; PCA; surface sediments

\section{ABSTRAK}

Sebatian individu dan sumber hidrokarbon aromatik polisiklik (HAP) telah dikaji di dalam sedimen permukaan pada 32 lokasi sekitar kawasan pelancongan di Pulau Langkawi. Sebanyak 15 HAP telah dikenal pasti dan dikira dengan menggunakan kromatografi gas yang digabungkan dengan spektometri jisim (GC-MS). Jumlah kepekatan HAP pada sedimen permukaan di Pulau Langkawi berjulat daripada 229.13 sehingga $990.25 \mathrm{ng} / \mathrm{g}$ dan diklasifikasikan sebagai pencemaran pada julat tahap rendah sehingga sederhana. Kesemua stesen pensampelan didominasi oleh HAP yang mempunyai berat molekul yang tinggi dengan 4 cincin (31.59\%) dan 5-6 cincin (42.73\%). Keputusan nisbah diagnosis juga menunjukkan bahawa kebanyakan stesen pensampelan tersebut mempunyai input pirogenik. Analisis selanjutnya menggunakan analisis prinsip komponen (PCA) yang digabungkan dengan prinsip komponen skor mutlak (APCS) dan linear regresi pelbagai (MLR) menunjukkan bahawa pelepasan gas asli menyumbang kepada 57\% jumlah keseluruhan kepekatan HAP, 22\% daripada pembakaran bahan api yang tidak lengkap dan pirolisis minyak, 15\% daripada sumber pirogenik dan petrogenik dan $6 \%$ daripada sumber yang tidak diketahui puncanya.

Kata kunci: APCS; HAP; MLR; nisbah diagnosis; PCA; sedimen permukaan

\section{INTRODUCTION}

Polycyclic Aromatic Hydrocarbons (PAHs) consist of two or more benzene rings and are one of the most important types of environmental pollutants. 16 PAHs have been categorized as 'highlighted pollutants' by the United State Environmental Protection Agency (US EPA) due to their mutagenic, toxic, persistent and carcinogenic characteristics (Gu et al. 2013; Sverdrup et al. 2002; Zhang et al.2012). As these compounds are hydrophobic, they are likely to adsorb onto the particulate phase, making marine sediments a reservoir for these compounds (Karickhoff 1984; Kucuksezgin et al. 2012). These compounds are mostly related to human activities and urban development (Page et al. 1999; Pietzsch et al.2010). They are introduced to aquatic environments via oil spill accidents, vehicular emissions, urban run-off and other combustion activities (Ying et al. 2008). Several PAHs are known to be highly carcinogenic to humans, such as benza[a]anthracene, chrysene, benzo[b]fluoranthene, benzo[k]fluoranthene, benzo[a]pyrene and benzo[ghi]perylene (IARC 1983; Luca et al. 2005; Vaezzadeh et al. 2014).

There are two types of anthropogenic sources of PAHs: petrogenic and pyrogenic. Combustion of fossil fuel is the main contributor to pyrogenic sources (Wang et al. 2009) while oil spill accidents contribute to petrogenic sources (Jiang et al. 2009; Yunker et al. 2002). The molecular ratio between low molecular weight (LMW) and high molecular weight (HMW) PAHs has been used to determine possible sources (Gschwend \& Hites 1981; Sicre et al. 1987; Soclo et al. 2000). Specific compounds, such as phenanthrene/ anthracene, fluoranthene/pyrene and benzo[a]anthracene/ chrysene, have been used to differentiate between petrogenic and pyrogenic sources (Baumard et al. 1998; Budzinski et al. 1997; Sicre et al. 1987; Soclo et al. 2000; 
Yunker et al. 2002). Ratios of PAH compositions such as Ant/(Ant+Phe) and Fluo/(Fluo/Pyr) have been used to give a precise evaluation of PAH sources (Yunker et al. 2002).

Studies on PAH concentrations mostly focus on their ability to accumulate with suspended particles in the water column and settle as sediment within a specific time frame (Guo et al. 2007). In previous studies, the source apportionment in island and tourism port area indicated mixed sources of PAHs in the sediments, but they largely originate from pyrolytic sources (Guo et al. 2007; Nasher et al. 2013; Vaezzadeh et al. 2014). This can be seen in the study by Vaezzadeh et al. (2014) in that the ratios of LMW to HMW PAHs were in the range $0.05-0.33$, indicating pyrogenic sources. Anthropogenic PAH inputs were more likely to be abundant at sites related to industrial discharges, shipping activities (dry docking) and sewage outfalls (Hosseini et al. 2012).

The aim of the current research was to study the distribution of PAHs in sediments around one of the busiest tourism island areas in Malaysia: The Langkawi Islands and its group of islands. The study determined the individual compounds and the proportions of compounds with differing numbers of molecular ring. This research also aimed to distinguish and identify the sources of PAHs in the surface sediments of the Langkawi Islands by various methods such as conventional diagnostic ratio and by employing a multivariate statistical technique which used principal component analysis (PCA) combined with absolute principle component score (APCS) and multiple linear regressions (MLR) (PCA-APCS-MLR).

\section{MATERIALS AND METHODS}

\section{DESCRIPTION OF SAMPLING LOCATION}

The Langkawi Archipelago with its 104 islands is situated in the Malacca Straits, located to the northwest of Peninsular Malaysia. Langkawi Island, the largest and most exploited island, covers an area of $479.5 \mathrm{~km}$ (Nasher et al. 2013). In an effort to promote Langkawi as one of the major tourist destinations in Malaysia, the island was designated as a National Geopark in 2006. In the following year, it was officially named a UNESCO Global Geopark (LADA 2011; Nasher et al. 2013). Due to these awards, Langkawi was visited by 2.4 million tourists in 2010 (LADA 2011; Nasher et al. 2013). From around 40,000 inhabitants in 1991, the population has increased to approximately 100,000 in 2010 (Nasher et al. 2013; Samat 2010). This was mainly to cope with the higher demands of tourism-related activities (Nasher et al. 2013). The predominant mode of transport between the islands is boat or ferry and the high amount of boating activity contributes to the increase of petroleum and diesel pollution around the islands.

Sampling was conducted from 3 - 4 March 2013 during sunny days and at low tide. Sediment samples were collected from 32 locations (Figure 1) around Langkawi Island based on the characteristics of the sampling stations, such as the proximity to the harbour, port, resorts, land fill or open sea. Descriptions of the sampling stations are shown in Table 1(a)-(b).

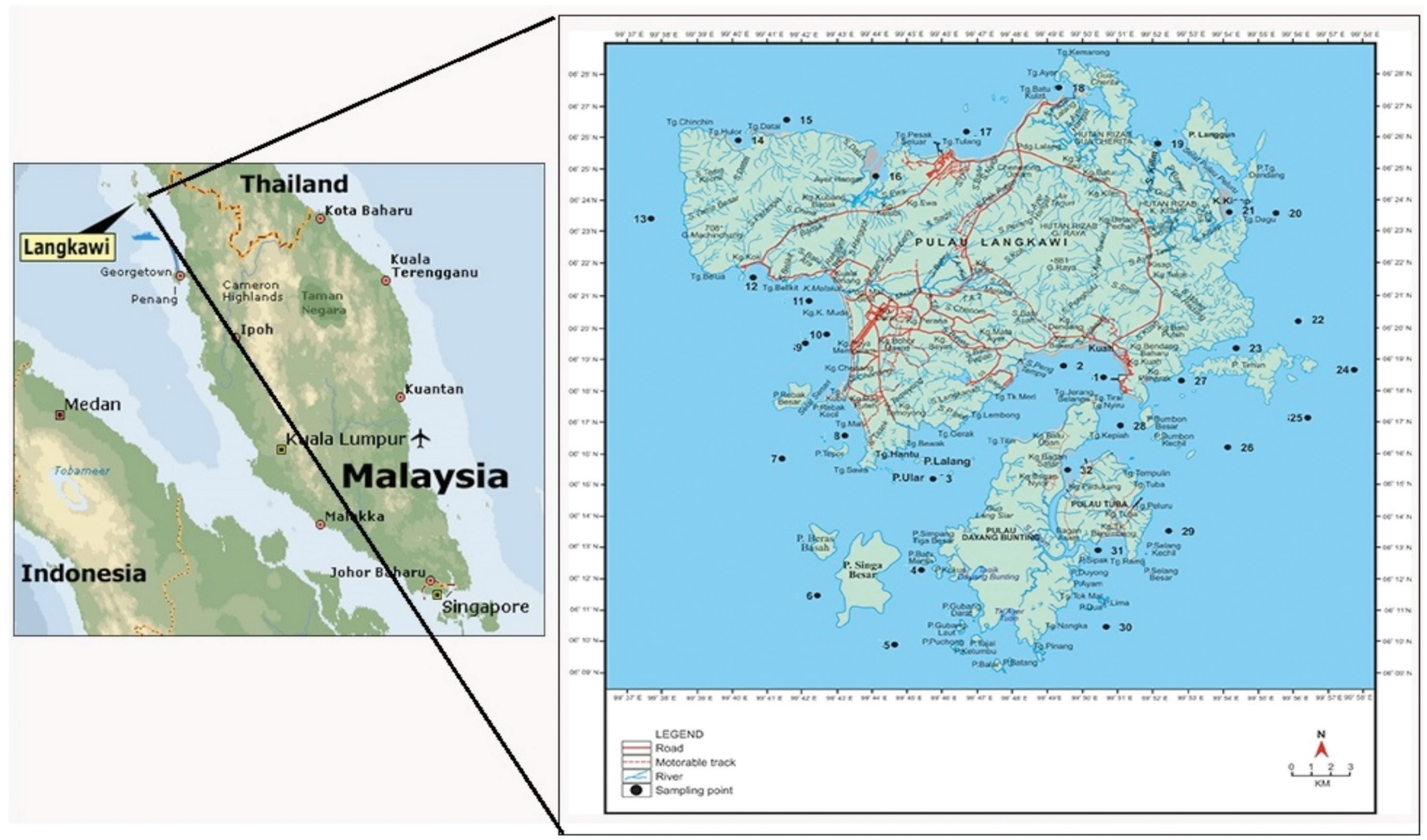

FIGURE 1. Sampling stations around Langkawi Island, Kedah 
TABLE 1(a). Description of sampling stations (Stations 1-19) around Langkawi Island, Kedah

\begin{tabular}{|c|c|c|c|c|c|}
\hline Station & Descriptions of sampling stations & $\begin{array}{l}\text { Depth of water } \\
\text { column }(\mathrm{m})\end{array}$ & $\begin{array}{l}\text { Latitude } \\
(\mathrm{N})\end{array}$ & $\begin{array}{l}\text { Longitude } \\
\text { (E) }\end{array}$ & Sampling date \\
\hline 1 & Kuah jetty & 5.1 & $6^{\circ} 18^{\prime} 27.81^{\prime \prime}$ & $99^{\circ} 50 ’ 39.31 "$ & 4-Mar-13 \\
\hline 2 & Residential/town area & 4.5 & $6^{\circ} 18^{\prime} 53.96 ”$ & $99^{\circ} 49^{\prime} 33.70^{\prime \prime}$ & 4-Mar-13 \\
\hline 3 & Closed sea surrounded by islands & 7.3 & $6^{\circ} 15^{\prime} 07.09^{\prime \prime}$ & $99^{\circ} 45^{\prime} 51.84^{\prime \prime}$ & 4-Mar-13 \\
\hline 4 & Fish farm area & 9.5 & $6^{\circ} 12^{\prime} 15.76^{\prime \prime}$ & $99^{\circ} 45^{\prime} 23.15^{\prime \prime}$ & 3-Mar-13 \\
\hline 5 & Open sea & 11.2 & $6^{\circ} 09^{\prime} 57.32^{\prime \prime}$ & $99^{\circ} 44^{\prime} 45.92^{\prime \prime}$ & 3-Mar-13 \\
\hline 6 & Open sea & 14.2 & $6^{\circ} 11^{\prime} 24.08^{\prime \prime}$ & $99^{\circ} 42^{\prime} 24.65^{\prime \prime}$ & 3-Mar-13 \\
\hline 7 & Open sea & 12.9 & $6^{\circ} 15^{\prime} 54.46^{\prime \prime}$ & $99^{\circ} 41^{\prime} 20.89^{\prime \prime}$ & 4-Mar-13 \\
\hline 8 & Chenang beach/resorts area & 5.3 & $6^{\circ} 16^{\prime} 41.53^{\prime \prime}$ & $99^{\circ} 43^{\prime} 12.52$ & 4-Mar-13 \\
\hline 9 & Open sea ( $2 \mathrm{~km}$ from Station 10$)$ & 5.4 & $6^{\circ} 19^{\prime} 30.77^{\prime \prime}$ & $99^{\circ} 42^{\prime} 04.27^{\prime \prime}$ & 4-Mar-13 \\
\hline 10 & Near airport & 3.6 & $6^{\circ} 19^{\prime} 41.30^{\prime \prime}$ & $99^{\circ} 42^{\prime} 45.50^{\prime \prime}$ & 4-Mar-13 \\
\hline 11 & Residential area & 3.8 & $6^{\circ} 20^{\prime} 49.71^{\prime \prime}$ & $99^{\circ} 42^{\prime} 10.35^{\prime \prime}$ & 4-Mar-13 \\
\hline 12 & Telaga harbour area & 5.8 & $6^{\circ} 21^{\prime} 34.88^{\prime \prime}$ & $99^{\circ} 40^{\prime} 41.20^{\prime \prime}$ & 4-Mar-13 \\
\hline 13 & Open sea & 13.8 & $6^{\circ} 23^{\prime} 43.10^{\prime \prime}$ & $99^{\circ} 37^{\prime} 44.69^{\prime \prime}$ & 4-Mar-13 \\
\hline 14 & Golf club resort area & 6.6 & $6^{\circ} 25^{\prime} 55.92 "$ & $99^{\circ} 40^{\prime} 11.36^{\prime \prime}$ & 4-Mar-13 \\
\hline 15 & Rural area & 14.8 & $6^{\circ} 26^{\prime} 31.59 \prime$ & $99^{\circ} 41^{\prime} 39.98^{\prime \prime}$ & 4-Mar-13 \\
\hline 16 & River estuary area & 1.4 & $6^{\circ} 24^{\prime} 55.60^{\prime \prime}$ & $99^{\circ} 44^{\prime} 00.69^{\prime \prime}$ & 4-Mar-13 \\
\hline 17 & Quarry area & 8.8 & $6^{\circ} 26^{\prime} 03.48^{\prime \prime}$ & $99^{\circ} 46^{\prime} 46.90^{\prime \prime}$ & 4-Mar-13 \\
\hline 18 & Open sea & 8.8 & $6^{\circ} 27 ' 31.16^{\prime \prime}$ & $99^{\circ} 49^{\prime} 22.97^{\prime \prime}$ & 4-Mar-13 \\
\hline 19 & Kilim Geopark area & 5.6 & $6^{\circ} 25^{\prime} 49.99 \prime$ & $99^{\circ} 52^{\prime} 11.70^{\prime \prime}$ & 4-Mar-13 \\
\hline
\end{tabular}

TABLE 1(b). Description of sampling stations (Station 20-32) around Langkawi Island, Kedah

\begin{tabular}{|c|c|c|c|c|c|}
\hline Station & Descriptions of sampling stations & $\begin{array}{l}\text { Depth of water } \\
\text { column (m) }\end{array}$ & $\begin{array}{l}\text { Latitude } \\
(\mathrm{N})\end{array}$ & $\begin{array}{l}\text { Longitude } \\
\text { (E) }\end{array}$ & Sampling date \\
\hline 20 & Open sea (facing peninsular mainland) & 6.3 & $6^{\circ} 23^{\prime} 31.50^{\prime \prime}$ & $99^{\circ} 55^{\prime} 26.14^{\prime \prime}$ & 4-Mar-13 \\
\hline 21 & River estuary area & 1.9 & $6^{\circ} 23^{\prime} 40.15^{\prime \prime}$ & $99^{\circ} 54^{\prime} 08.61^{\prime \prime}$ & 4-Mar-13 \\
\hline 22 & Open sea & 7.1 & $6^{\circ} 20^{\prime} 17.59^{\prime \prime}$ & $99^{\circ} 56^{\prime} 01.35^{\prime \prime}$ & 4-Mar-13 \\
\hline 23 & Ferry route & 6.6 & $6^{\circ} 19^{\prime} 27.91^{\prime \prime}$ & $99^{\circ} 54^{\prime} 20.48^{\prime \prime}$ & 4-Mar-13 \\
\hline 24 & Open sea & 15.9 & $6^{\circ} 18^{\prime} 44.65^{\prime \prime}$ & $99^{\circ} 57^{\prime} 56.78^{\prime \prime}$ & 4-Mar-13 \\
\hline 25 & Open sea & 14.3 & $6^{\circ} 17^{\prime} 01.16^{\prime \prime}$ & $99^{\circ} 56^{\prime} 19.99^{\prime \prime}$ & 4-Mar-13 \\
\hline 26 & Open sea & 6.4 & $6^{\circ} 16^{\prime} 04.29^{\prime \prime}$ & $99^{\circ} 54^{\prime} 04.32^{\prime \prime}$ & 4-Mar-13 \\
\hline 27 & Ferry route & 5.1 & $6^{\circ} 18^{\prime} 17.42^{\prime \prime}$ & $99^{\circ} 52 ’ 57.04^{\prime \prime}$ & 4-Mar-13 \\
\hline 28 & Ferry route & 9.2 & $6^{\circ} 16^{\prime} 55.25^{\prime \prime}$ & $99^{\circ} 51^{\prime} 01.48^{\prime \prime}$ & 3-Mar-13 \\
\hline 29 & Rural area & 11.2 & $6^{\circ} 13^{\prime} 24.69^{\prime \prime}$ & $99^{\circ} 52^{\prime} 25.34^{\prime \prime}$ & 3-Mar-13 \\
\hline 30 & Open sea & 11.8 & $6^{\circ} 10^{\prime} 19.75^{\prime \prime}$ & $99^{\circ} 50^{\prime} 44.19^{\prime \prime}$ & 3-Mar-13 \\
\hline 31 & Bay/rural area & 2.5 & $6^{\circ} 12^{\prime} 58.15^{\prime \prime}$ & $99^{\circ} 50^{\prime} 22.92^{\prime \prime}$ & 3-Mar-13 \\
\hline 32 & Residential area & 3.3 & $6^{\circ} 15^{\prime} 22.20^{\prime \prime}$ & 9949'37.19”' & 3-Mar-13 \\
\hline
\end{tabular}

\section{SAMPLE PREPARATION}

Sediment samples were collected using a Ponar 'Grab' sampler and the sediment was placed in a stainless steel pan. The samples were then transferred into a glass jar and kept in the ice chest. After reached the laboratory, the samples were refrigerated at $-4^{\circ} \mathrm{C}$ in the laboratory until further analysis.

\section{CHEMICALS AND REAGENTS}

This study focused on the analysis of fifteen PAHs, namely naphthalene (Naph), fluorine (Flu), phenanthrene (Phe), anthracene (Ant), fluoranthene (Fluo), pyrene (Pyr), benzo[a]anthracene (BaA), chrysene (Chry), benzo[b]fluoranthene $(\mathrm{BbF})$, perylene (Per), benzo[k] fluoranthene $(\mathrm{BkF})$, Benzo[e]pyrene $(\mathrm{BeP})$, dibenzo[a,h] anthracene (BahA), indeno[1,2,3,cd]pyrene (IP) and benzo[g,h,i]perylene (BghiP). The native standards (L20950018AL) were purchased from Dr. Ehrenstorfer $\mathrm{GmbH}$, Germany and were injected individually into the gas chromatography coupled with mass spectrometer (GC-MS) as an external standard to identify and quantify the target PAHs in the sample. The samples were spiked with two surrogate standards (phenanthrene-d10 and chrysene-d12) as surrogate internal standards prior to injection into the GC-MS for quantification of all PAHs analysed in this study. The silica gel columns (technical grade) with size 0.063-0.200 mm for column chromatography were purchased from Aldrich Chemistry, USA and were baked at $400^{\circ} \mathrm{C}$ for $4 \mathrm{~h}$ to remove organic contaminants and then activated at $200^{\circ} \mathrm{C}$ for $2 \mathrm{~h}$. 


\section{ANALYTICAL PROCEDURES}

The collected sample were analysed according to procedures described by Zakaria et al. (2002). Approximately $20 \mathrm{~g}$ of each sample were homogenized with a stainless steel spoon, and dried with anhydrous sodium sulphate (Merck KGaA, Germany). After that, it was Soxhlet-extracted with $250 \mathrm{~mL}$ dichloromethane (DCM) (Merck KGaA, Germany) for 6-8 h. The DCM extract containing the organic pollutants was transferred to a $250 \mathrm{~mL}$ round bottom flask and the extract was reduced to a small volume using a rotary evaporator and then purified and fractioned into aliphatic and aromatic fractions using a two-step silica gel chromatography column process. This separated most of the organic pollutants, including n-alkanes, linear alkyl benzenes (LABs), Polychlorinated Bipenhyls (PCBs), pesticides and PAHs, from other unwanted polar compounds. The concentrated sample extracts were transferred on the top of the silica gel column (first step column chromatography) then rinsed with $2 \mathrm{~mL}$-hexane/ dichloromethane (3:1) and followed by another $18 \mathrm{~mL}$ of mixture n-hexane/dichloromethane (3:1). Hydrocarbons ranging from n-alkanes to PAHs were diluted through the column and collected in a pear-shaped flask. The second step column chromatography was performed to separate the n-alkane and hopane, LAB and PAH fractions. The eluent from the first step column chromatography was concentrated to $1-5 \mathrm{~mL}$ by a rotary evaporator and further concentration was performed using a gentle stream of purified nitrogen to near dryness. The PAH fraction as the third fraction was treated with $16 \mathrm{~mL} \mathrm{DCM:n-Hexane}$ (1:3). After that, the volume of the PAHs fraction was reduced by using a rotary evaporator to near dryness and was transferred into a $2 \mathrm{~mL}$ vial. Then it underwent nitrogen blow down evaporation and was refilled with distilled n-hexane prior to the injection into the GC-MS (GC, 6890N coupled with 5975C MSD, Agilent, USA). The carrier gas was helium at a fixed rate of $1 \mathrm{~mL} / \mathrm{min}$ with a pressure of $158 \mathrm{kpa}$. A HP- 5 fused silica capillary column ( $30 \mathrm{~m} \times 0.25 \mathrm{~mm}$ i.d. and 0.25 um thickness) was used to separate the compounds in split-less mode at $270^{\circ} \mathrm{C}$. The GC temperature gradient was at $40^{\circ} \mathrm{C}$ then increased at $8^{\circ} \mathrm{C} / \mathrm{min}$ to $150^{\circ} \mathrm{C}$, then at $5^{\circ} \mathrm{C} / \mathrm{min}$ to $310^{\circ} \mathrm{C}$ and finally held for about ten $\mathrm{min}$. The GC-MS operating conditions were $70 \mathrm{eV}$ ionisation potential with a MS source at $230^{\circ} \mathrm{C}$ for $1.4 \mathrm{scans} / \mathrm{s}$, electron multiplier at $1400 \mathrm{~V}$ and the dwell time set at $40 \mathrm{~s}$. The interface temperature was $280^{\circ} \mathrm{C}$ while the injector temperature was maintained at $250^{\circ} \mathrm{C}$. The 15 PAHs were quantified based on their retention time and the ion $\mathrm{m} / \mathrm{z}$ ratio of native standard PAHs.

\section{QUALITY CONTROL AND QUALITY ASSURANCE}

To ensure high accuracy and precision during the sample analyses, several pre-detection steps were applied. Firstly, blank and environmental samples were processed simultaneously to eradicate any cross-contamination during the study. We ensured optimal performance of the
GC-MS prior to the injection of the samples. The validation of PAH peaks was implemented based on the compatibility of each retention time and abundance of quantification ions of individual PAHs with the 15 PAH mixture, coupled with the surrogate standard. Furthermore, five-point external calibration curves (L20950018AL, Dr. Ehrenstorfer $\mathrm{GmbH}$, Germany) were established in the range 0.1-1.0 ppm with correlation coefficients higher than 0.990 . The Method Detection Limit (MDL) was also obtained to ensure the limit of detection for each individual PAH compounds. MDL values were calculated based on the following formula:

$$
\mathrm{MDL}=\mathrm{T}(\mathrm{n}-1,1-\alpha=0.99) \times \text { Standard Deviation }
$$

$\mathrm{T}_{(\mathrm{n}-1,1-\alpha=0.99)}$ is the student's $\mathrm{t}$ value appropriate for $99 \%$ confidence level and a standard deviation estimate with $\mathrm{n}-1$ degrees of freedom where $\mathrm{n}$ is the number of replicates collected for the MDL study. MDL values (ng/g) for Naph, Flu, Phe, Ant, Fluo, Pyr, BaA, Chry, BbF, Per, BkF, BeF, IP, BahA and BghiP were 4.47, 3.12, 0.70, 0.94, 3.53, 2.61, $1.10,3.02,1.91,3.18,6.58,2.25,7.63,2.38$ and 3.99, respectively. The recoveries for phenanthrene and chrysene were $68.66 \%$ and $87.00 \%$, respectively.

\section{MULTIVARIATE SOURCE APPORTIONMENT PROCEDURES}

The PCA-APCS-MLR technique is an advanced and robust method used in the study of source apportionment. The basic difference between APCS-MLR and PCA-MLR is the capacity to implement a zero correction in the APCS-MLR compared to PCA-MLR (Jamhari et al. 2014; Khan et al. 2010; Thurston et al. 2011). Briefly, PCA is a statistical approach, which is often used to reduce a large dataset to a small set of uncorrelated factors that can explain the most of the variance. Mathematically, PCA can be defined with the following equation proposed by Hopke (2003):

$$
x_{i k}=\sum_{j=1}^{p} g_{i k} f_{p k}+e_{i k}
$$

where $\mathrm{X}_{\mathrm{ik}}$ is the $\mathrm{i}^{\text {th }}$ species concentration of the $\mathrm{k}^{\text {th }}$ sample; $g_{\text {ip }}$ is the $i^{\text {th }}$ species concentration from the $p^{\text {th }}$ source; $f_{p k}$ is the $\mathrm{p}^{\text {th }}$ source contribution to the $\mathrm{k}^{\text {th }}$ sample and $\mathrm{e}_{\mathrm{ik}}$ is the error involved the analysis.

In order to find a rational and interpretable output and maximize the variance of the loading in all variables in factors, the PCA model was run with the varimax rotation method. Prior to the PCA run, the dataset of PAH concentrations was normalized using the methodology explained by Thurston and Spengler (1985) to avoid variation and insignificance in the results. Furthermore, the APCS from each PCA factor was estimated by introducing an artificial sample with zero concentration as explained in Thurston and Spengler (1985). Additionally, the MLR was employed considering the total PAHs as dependent and the APCS as independent variables to estimate the contribution of sources identified by PCA. 


\section{RESULTS AND DISCUSSION}

\section{DISTRIBUTION OF PAHS IN SURFACE SEDIMENTS}

The concentrations of 15 PAHs and their diagnostic ratios are shown in Table 2. The highest concentration of total PAHs was recorded at Station $3(990.25 \mathrm{ng} / \mathrm{g})$, while the lowest concentration was recorded at Station 26 (228.13 $\mathrm{ng} / \mathrm{g})$. The high concentrations of total PAHs were observed at stations near resorts areas such as Chenang Beach, the airport and Telaga Harbour (Table 2). For individual compounds, the highest $\mathrm{PAH}$ was $\mathrm{BkF}$ with $12 \%$ of the total PAHs while the lowest was Flu with only $2 \%$ of the total PAHs (Figure 3). The surface sediment samples from Langkawi Island were mostly dominated by $\mathrm{BkF}$ with value of $12 \%$. The high percentage of $\mathrm{BkF}$ was expected to originate from vehicle exhaust via incomplete combustion (Harrison et al. 1996; Luo et al. 2011).

Based the number of benzene rings, the highest percentage across all sampling stations is 4-ring PAHs with $31.59 \%$, followed by 5 -ring $(30.30 \%)$, 3-ring $(18.87 \%)$, 6-ring $(12.43 \%)$ and 2-ring $(6.81 \%)$ (Figure 4). Sampling stations in Langkawi Island were dominated by HMW PAHs, which are 4-6 fused aromatic benzene rings, compared to LMW PAHs with 2-3 fused aromatic benzene rings. Petrogenic PAHs are abundant in LMW PAHs while pyrogenic PAHs are dominated by HMW PAHs (combustion of fossil fuel and biomass) (Qiao et al. 2004; Sanders et al. 2002). There are two types of anthropogenic sources of PAHs which are pyrogenic and petrogenic source. Pyrogenic PAHs consists of high molecular weight (HMW) molecules with 4-7 fused aromatic benzene rings (Wang et al.2009) while petrogenic PAHs are abundant with low molecular weight (LMW) molecules containing 2-3 fused aromatic benzene rings (Jiang et al. 2009; Yunker et al. 2002). These findings suggest that PAH pollution at Langkawi Island sampling stations generally originated from pyrogenic sources. This result is supported by Nasher et al. (2013) who reported that their findings on Langkawi Island mostly originated from HMW PAHs compared to LMW PAHs.

In order to assess the current status of PAH pollution in Langkawi Island, concentrations of PAHs were compared with the data from previous studies at other places by Baumard et al. (1998) which defined two pollution levels, where $0-1000 \mathrm{ng} / \mathrm{g}$ PAHs in sediment was classified low to moderately polluted and 1000-10000 ng/g was classified as being moderately to highly polluted. For areas near tourism ports, total PAH concentration levels the sediments from Olbia harbour (a tourist harbour located in northern Sardinia, Italy) ranged from 160 to $770 \mathrm{ng} / \mathrm{g}$ (Luca et al. 2005), 1.4 to $205 \mathrm{ng} / \mathrm{g}$ for sediments from James Ross Island, Antartica (Klanova et al. 2007), 38.6 to $122.8 \mathrm{ng} / \mathrm{g}$ from Merambong Island, Johor, Malaysia (Vaezzadeh et al. 2014), 158 to $10463 \mathrm{ng} / \mathrm{g}$ from Suez Port (mixed industrialized and tourism port) and 2 to $59 \mathrm{ng} / \mathrm{g}$ in the ambient sediment of Kenting National Park, Taiwan (Ko et al. 2014). From the values suggested by Baumard et al. (1998) and some previous studies above, the results from this study show that PAHs from Langkawi Island are within the low to moderate pollution range.

\section{IDENTIFICATION OF PAH SOURCES BY DIAGNOSTIC RATIO}

The identification of PAH sources was determined by the diagnostic ratio between compounds. There are various diagnostic ratios that are suitable and have been used by many researchers to determine the sources of PAHs. The diagnostic ratios that were used in this study were the Phe/ Ant, Fluo/Pyr, BaA/Chry, Naph/Phe and the LMW/HMW PAH ratios. As shown in Table 2 for the Phe/Ant ratio, all stations' values were less than 10; this suggests a pyrogenic source. Meanwhile for the Fluo/Pyr ratio, all values were less than 1, which suggests a petrogenic source, typical of petroleum hydrocarbons (Khim et al. 1999). For the BaA/ Chry ratio, all values were greater than 1 , which suggests a petrogenic source. Furthermore, for the LMW/HMW ratio, all values were less than 1 except for Station 24, had a value of 1.60 indicates petrogenic source. For the Naph/Phe ratio, all values were less than 1 except for two sampling stations, which were Station 15 with 1.01 and Station 31 with 1.07 (both stations were in rural areas). These two values greater than 1 indicate a direct spillage of fresh petroleum. Despite the fact that these two sampling stations were within rural areas, it might be contributed to by ferries or boats that pass by every day and the potential accidental spillage of petroleum from the ferry or boat. Commonly, a Phe/Ant ratio of less than ten and a $\mathrm{Fl} / \mathrm{Pyr}$ ratio of greater than one emphasizes PAHs originating from combustion processes (Soclo et al. 2000).

As shown in Figure 5, sediment samples with a Phe/ Ant ratio of less than ten and a Fluo/Pyr ratio of less than one was characteristic of a mixed source of pyrogenic and petrogenic pollutants. The contrasting ratios might also disclose the level of photo-degradation or biodegradation and also the particle size of the sediment samples (Tam et al. 2001). Due to the uncertainty of sources resulting from the ratios that were calculated, Ant/(Ant+Phe) and Fluo/(Fluo/Pyr) ratios have been processed to distinguish the sources of PAHs in the sediments. As shown in Figure 6 , for the Ant/(Ant+Phe) ratio all the values were greater than 0.1 , which indicated a petroleum combustion source. Exceptions were Station 14, 26 and 28, whose ratios indicated some petroleum spillage. For the Fluo/(Fluo/Pyr) ratio, all the values were within 0.4 to 0.5 which indicates sources originating from petroleum combustion. A value of less than 0.4 indicates a petroleum spillage while values of greater than 0.5 indicate sources that originate from grass, wood and coal combustion (Riccardi et al. 2013; Saha et al. 2009; Yunker et al. 2002). The sediments in the tourism port sampling station in Olbia harbour, Italy which its characteristics almost similar to Langkawi Island as a major tourist oriented place also showed a pyrolytic contribution to pollution in the sediment (Luca et al. 2005). Contrary to that, most of the pollutants in the sediments around Langkawi Island originate from petrogenic sources. PCA was also carried out in this study to determine the sources 


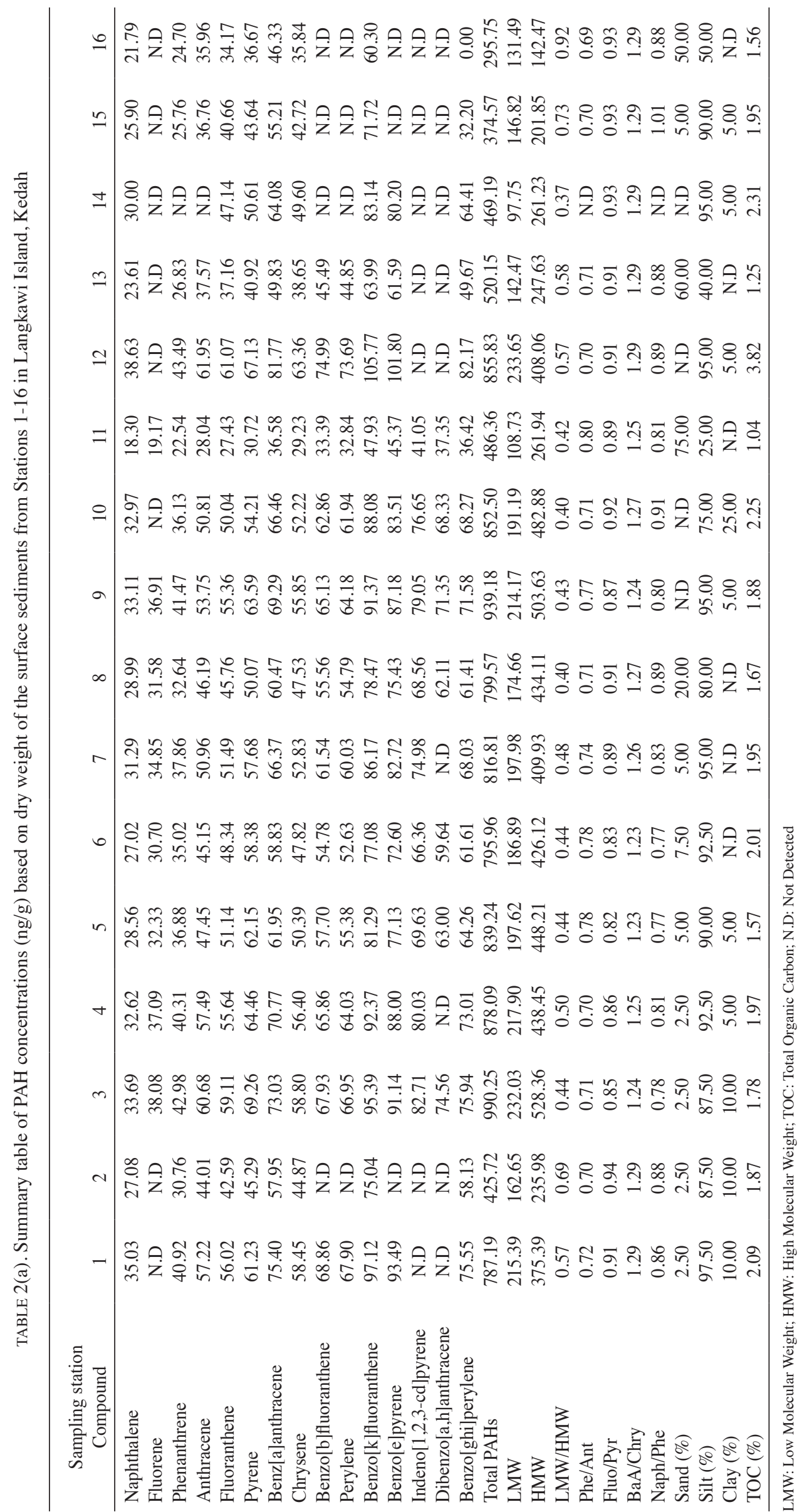




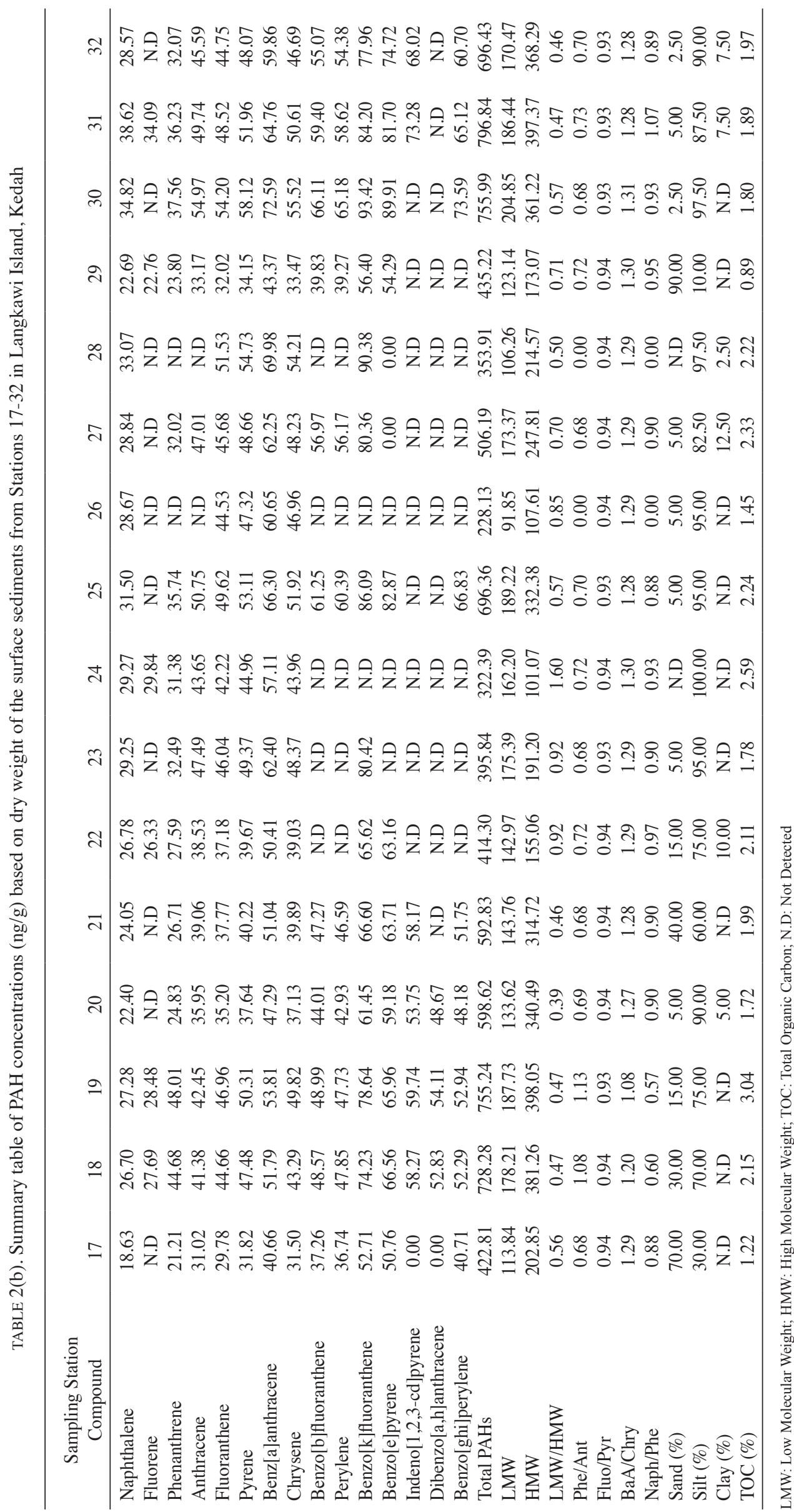




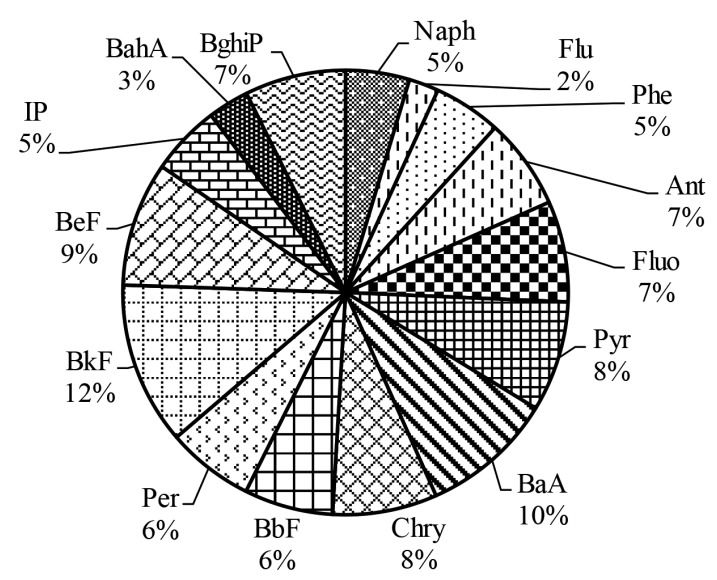

FIGURE 2. Total PAH percentage for each compound

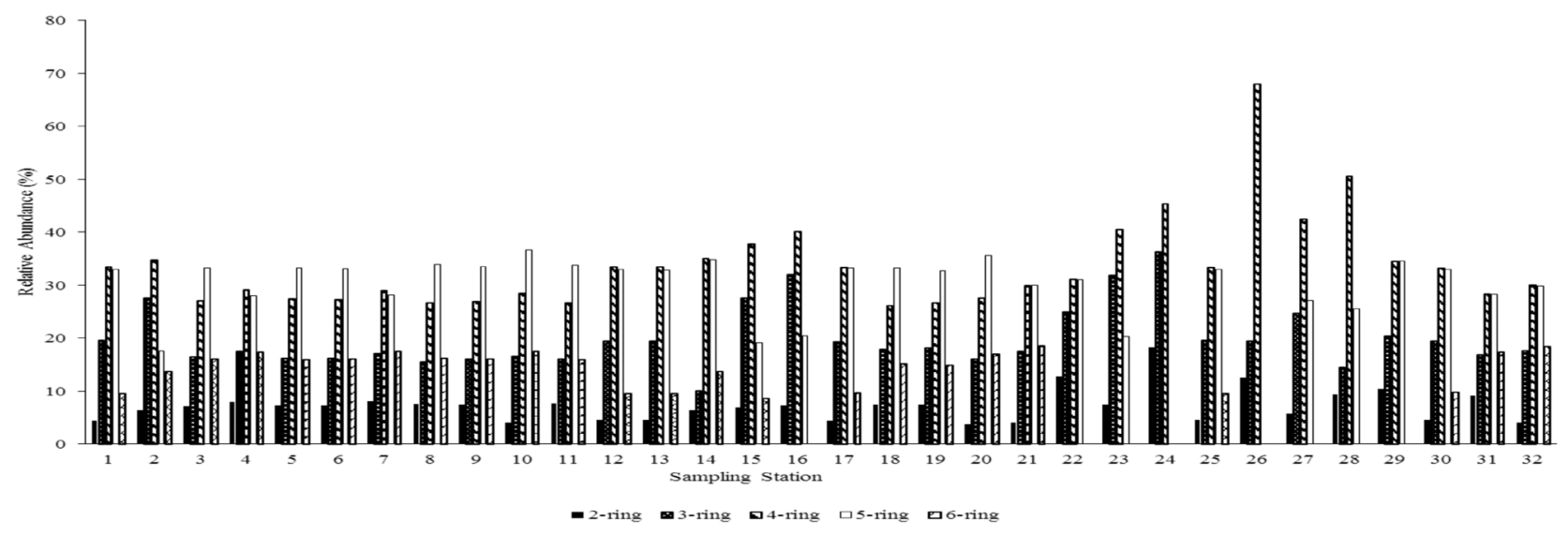

FIGURE 3. Relative distribution (\%) of 2-, 3-, 4-, 5-, and 6-ring PAHs in the sediments around Langkawi Island

of PAHs other than the conventional diagnostic ratios used earlier.

\section{SOURCE IDENTIFICATION OF PAHS BY PCA-APCS-MLR}

As utilized by many researchers in this field, the purpose of PCA is to demonstrate the total variation of PAHs data with the minimum number of the factor loadings. Each factor

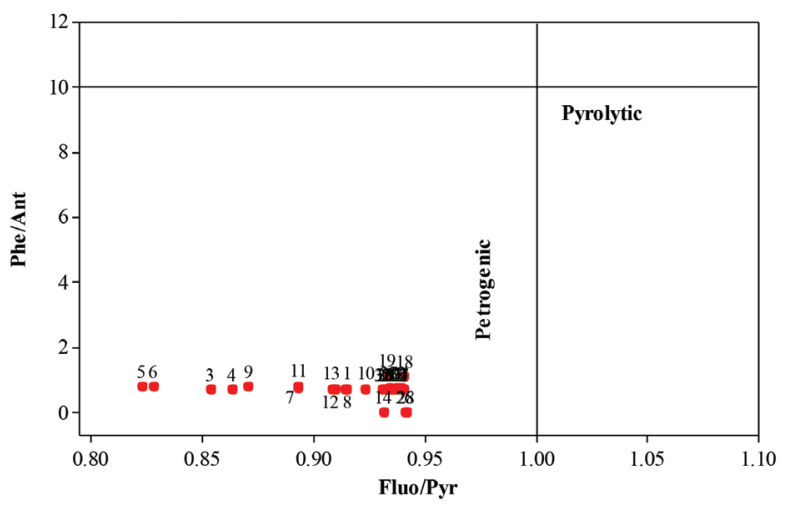

FIGURE 4. Phe/Ant against Fluo/Pyr plot diagram can be analysed by the identification of the availability of the sources responsible and accurately quantifying the percentage of individual PAH sources (Liu et al. 2009; Wang et al. 2009; Zhang et al. 2012). Identification was carried out with the principal component with eigenvalues of greater than one in order to get the significance between

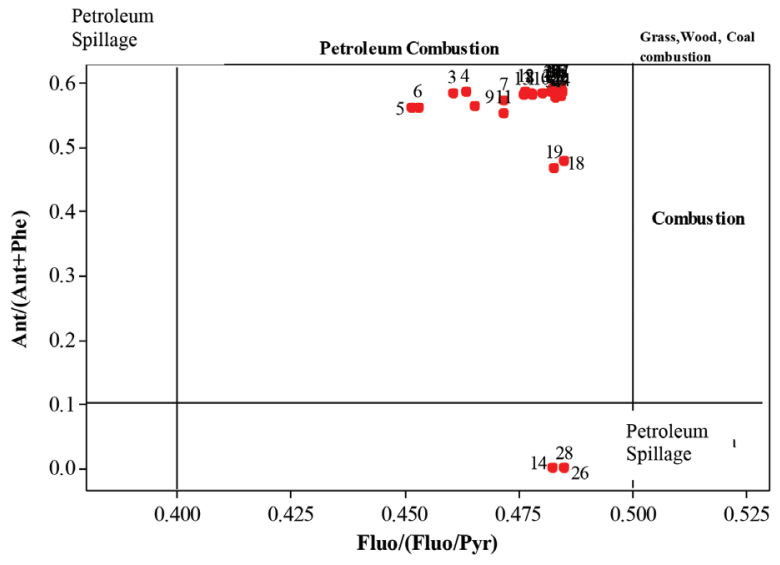

FIGURE 5. Ant/ (Ant+Phe) against Fluo/ (Fluo/Pyr) plot diagram 
the principal component and individual PAHs; PCA with Varimax rotation was performed to indicate their factor loadings. This type of analysis has been proven to be able to increase the weight of the significant factor loadings by the varimax rotation in PCA and thus reduce the weight of the non-significant ones (Simenov et al.2002). According to Osman et al. (2012), values falling within 0.5-0.75 are considered to have moderate loading while strong loading is indicated by values above 0.75 . As shown in Table 3, PCA analysis arranged the dataset of PAHs into three principle components (PCs) that control $81.86 \%$ of the variability of the data.

The first factor (F1) explained $54.71 \%$ of the variance of the total data. The weight of this factor was contributed to by strong loading of Naph, Fluo, Pyr, BaA and Chry. Naph is a typical marker of the spillage of petroleumbased products and thus classified as a petrogenic source (Dobbins et al. 2006; Luca et al. 2005; Marr et al. 1999; Zakaria et al. 2002). Fluo, Pyr, BaA and Chry are tracers for the emission of natural gas (Motelay-Massei et al. 2007; Park et al.2011). F1 sources are thought to mostly originate from pyrogenic sources caused by coal combustion and the emission of natural gas. The second factor (F2) explained $18.49 \%$ the variance of the total data. The weight of this factor was generally contributed to by the heavy loading of Phr, Ant, BbF, Per, BeP and BghiP. HMW PAHs with 5-6 rings were predominant in this factor and are generally expelled from the incomplete combustion and pyrolysis of fuel (Chen et al. 2012; Zhang et al. 2012). Thus, F2 has been classified as the incomplete combustion and pyrolysis of fuel. The third factor (F3) explained $8.76 \%$ of the variance of the total data. The weight of this factor was contributed to by Flu, IP and BahA. Flu is a petrogenic PAH and belongs to the alkyl-substituted PAHs with 2-3 rings. It is thought to have originated from fresh or used oil spills, accidents that contribute to marine and land pipeline leakage (Liu et al. 2009; Riccardi et al. 2013; Saha et al. 2009; Zakaria et al. 2001). IP (a 6 ring PAH) and BahA (a 5 ring $\mathrm{PAH}$ ) are HMW PAHs which originate from incomplete combustion of fossil fuel such as heating oil, cooking and waste tyres (Beyer et al. 2010; Khairy et al. 2009; Saha et al. 2009). Therefore, F3 consists of mixed sources such as petrogenic and pyrogenic sources.

In order to calculate the percentages of the contribution of each source, APCS and MLR was carried out. The calculations show that natural gas emissions contribute to $57 \%$ of the total PAH concentrations, $22 \%$ from the incomplete combustion and pyrolysis of fuel, $15 \%$ from mixed pyrogenic and petrogenic sources and $6 \%$ from an undefined source. Possible major sources of PAHs in Langkawi Island were thought to be from natural gas emissions such as traffic emissions from both land and sea vehicles. Atmospheric transportation and dry or wet deposition favour the pathway of spreading exhaust from vehicles, including cars, motorbikes, ferries or boats (Fang et al. 2004). Smoke or exhaust fumes released into the atmosphere are easily absorbed into particles and deposited onto the road surface or soil and then swept into the aquatic
TABLE 3. Rotated component matrix of 15 PAHs from the Langkawi Island surface sediment

\begin{tabular}{lccc}
\hline Compound & F1 & F2 & F3 \\
\hline Naph & $\mathbf{0 . 9 3}$ & 0.21 & 0.01 \\
Flu & 0.09 & 0.12 & $\mathbf{0 . 8 5}$ \\
Phr & 0.16 & $\mathbf{0 . 7 5}$ & 0.31 \\
Ant & 0.21 & $\mathbf{0 . 7 7}$ & 0.15 \\
Fluo & $\mathbf{0 . 9 4}$ & 0.28 & 0.15 \\
Pyr & $\mathbf{0 . 9 0}$ & 0.31 & 0.26 \\
BaA & $\mathbf{0 . 9 7}$ & 0.21 & -0.05 \\
Chry & $\mathbf{0 . 9 6}$ & 0.25 & 0.07 \\
BbF & 0.22 & $\mathbf{0 . 8 9}$ & 0.22 \\
Per & 0.22 & $\mathbf{0 . 8 9}$ & 0.22 \\
BkF & 0.53 & 0.59 & -0.05 \\
BeF & 0.25 & $\mathbf{0 . 7 7}$ & 0.25 \\
IP & 0.09 & 0.42 & $\mathbf{0 . 7 9}$ \\
BahA & 0.00 & 0.24 & $\mathbf{0 . 8 1}$ \\
BghiP & 0.36 & $\mathbf{0 . 7 5}$ & 0.19 \\
Eigenvalue & 8.21 & 2.77 & 1.31 \\
Total variance (\%) & 54.71 & 18.49 & 8.76 \\
Cumulative (\%) & 54.71 & 73.20 & 81.96 \\
\hline
\end{tabular}

Bold number: Loading value more than 0.7 (Heavy Loading)

environment by run-off (Boonyatumanond et al. 2006; Murakami et al 2005).

\section{TOTAL ORGANIC CARBON (TOC) AND PARTICLE GRAIN SIZE}

The particle grain size of sediments around Langkawi Island in this study consisted mostly of silt, with a total percentage from around $10 \%$ at Station 29 to $100 \%$ at Station 24 (Table 2). Total organic carbon (TOC) in this study ranged from $0.89 \%$ recorded at Station 29 and $3.82 \%$ recorded at Station 12, near Telaga Harbour. A high TOC value was also recorded at Station 19, which was in the Kilim Geopark Area. As suggested in a study by Nasher et al. (2013), the sampling station is near a mangrove area and thus receives discharge from biological productivity and has a high sedimentation rate. The high biological productivity will accumulate more organic wastage that secreted by them into the sediment (Ramaswamy et al. 2008). High sedimentation rates can induce the contact time between organic matter and dissolved oxygen in the water column and therefore can contribute to higher concentrations of organic carbon sediment (Pierson et al. 2002). There is a low concentration of TOC at Station 29 , which is located in a rural area, because this station has low biological productivity (Nasher et al. 2013). Based on the study carried out by Bathi et al. (2009), most of the concentrations of PAHs were associated with the smaller size particle of the sediments thus contributes to the positive correlation between PAHs concentration and smaller size particle of sediment. Another study which also conducted by CSIRO Huon Estuary study team (2000) stated that organic matter has a high affinity for fine-grained sediment because it adsorbs onto mineral surfaces. The adsorption process helps to preserve the organic matter, and given rise to a generally positive correlation between 
TOC and finer size of the sediment. In this study, there was no correlation found between total PAHs and TOC with particle grain size (Table 4). For correlations between TOC and particle grain size, there was a high negative correlation between silt and sand $(-0.976, \alpha=0.05)$ and between TOC and sand $(-0.585, \alpha=0.05)$. There was also a high correlation between silt and TOC $(0.546, \alpha=0.05)$. Therefore, PAHs and TOC in sediments were not influenced by the grain size in the sediment around Langkawi Island. TOC in the sediments is somewhat influenced by the silt content in the sediments.

TABLE 4. Total PAHs, particle size and TOC correlation table

\begin{tabular}{lcccc}
\hline Variables & Total PAH & Sand $(\%)$ & Silt $(\%)$ & Clay $(\%)$ \\
\hline Total PAH & & & & \\
Sand (\%) & -0.335 & & & \\
Silt (\%) & 0.294 & $-0.976^{*}$ & & \\
Clay (\%) & 0.275 & $-0.403^{*}$ & 0.219 & \\
TOC (\%) & 0.275 & $-0.601^{*}$ & $0.563^{*}$ & 0.224 \\
\hline
\end{tabular}

*Significant at level $\alpha=0.05$

\section{CONCLUSION}

The degree of PAH pollution at Langkawi Island ranges from 228.13 to $990.25 \mathrm{ng} / \mathrm{g}$ and can be described as low to moderate compared to PAH concentration studies that have been previously conducted. The source determination of PAHs in Langkawi Island sediments was based on individual compound distribution, diagnostic ratios application and PCA-APCS-MLR. The results of the individual distributions of PAHs showed that pyrogenic sources are the main source of PAHs at most stations because of high dominations of HMW PAHs with 4-rings (31.59\%), 5-rings (30.30\%) and 6-rings $(12.43 \%)$. Station 24 (near the open sea facing the mainland peninsula) seems to show petrogenic input (LMW/ HMW > 1.0) because of slightly higher LMW PAHs, which contribute significantly to the total PAHs at this station. The results of the diagnostic ratios (Ant/ (Ant+Phe) $>0.1$; Fluo/ (Fluo+Pyr): 0.4-0.5) showed that PAHs in most sediments in all sampling stations originated from the combustion of petroleum products. PCA-APCS-MLR indicated that natural gas emissions contributed to $57 \%$ of total PAHs concentration, while $22 \%$ originated from the incomplete combustion and pyrolysis of fuel, $15 \%$ from a combination of pyrogenic and petrogenic sources and 6\% from an undefined source. Most natural gas emissions contributing to the PAHs source originate from commercial ferries, boats and vehicle traffic on the main island of Langkawi.

\section{ACKNOWLEDGEMENTS}

The authors would like to thank the Ministry of Science, Technology and Innovation of Malaysia (MOSTI) and Universiti Kebangsaan Malaysia for the E-science Fund 04-01-02-SF0698 and DPP-2014-162 research grants.

\section{REFERENCES}

Bathi, J.R., Pitt, R. \& Clark, S.E. 2009. Associations of PAHs with size fractioned sediment particles. World Env. \& Water Res. Cong. 342: 1-10.

Beyer, J., Jonsson, G., Porte, C., Krahn, M.M. \& Ariese, F. 2010. Analytical methods for determining metabolites of polycyclic aromatic hydrocarbon $(\mathrm{PAH})$ pollutants in fish bile: A review. Environ. Toxico. Pharm. 30: 224-244.

Boonyatumond, R., Wattayakorn, G., Togo, A. \& Takada, H. 2006. Distribution and origins of polycyclic aromatic hydrocarbons (PAHs) in riverine, estuaries, and marine sediments in Thailand. Mar. Poll. Bull. 52(8): 942-956.

Budzinski, H., Jones, I., Bellocq, J., Pie’' rard, C. \& Garrigues, P. 1997. Evaluation of sediment contamination by polycyclic aromatic hydrocarbons in the Gironde estuary. Mar. Chem. 58: 85-97.

Chen, H., Teng, Y. \& Wang, J. 2012. Source apportionment of polycyclic aromatic hydrocarbons (PAHs) in surface sediments of the Rizhao coastal area (China) using diagnostic ratios and factor analysis with nonnegative constraints. Sci. Total Environ. 414: 293-300.

CSIRO Huon Estuary Study Team. 2000. Environmental research for integrated catchment management and aquaculture. Project No. 96/284. Final Report to the Fisheries Research \& Development Cooperation. pp. 285-311.

De Luca, G., Furesi, A., Micera, G., Panzanelli, A., Piu, P.C., Pilo, M.I., Spano, N. \& Sanna, G. 2005. Distribution and origin of polycylic aromatic hydrocarbons (PAHs) in the sediments of Olbia harbor (northern Sardinia, Italy). Mar. Poll. Bull. 50: 1223-1232.

Dobbins, R.A., Fletcher, R.A., Benner, Jr. B.A. \& Hoeft, S. 2006. Polycyclic aromatic hydrocarbons in flames, in diesel fuels, and in diesel emission. Combust Flame 144: 773-781.

Fang, X.Y., Jiang, W.M., Miao, S.G., Zhang, N., Xu, M., Ji, C.P., Chen, X.Y., Wei, J.M., Wang, Z.H. \& Wang, X.Y. 2004 The multi-scale numerical modeling system for research on the relationship between urban planning and meteorological environment. Adv. Atm. Sci. 21: 103-112.

Gschwend, P.M. \& Hites, R.A. 1981. Fluxes of polycyclic aromatic hydrocarbons to marine and lacustrine sediments in the northeastern US. Geochim. Cosmochim. Acta 45: 2359-2367.

Gu, Y., Lin, Q., Lu, T., Ke, C., Sun, R. \& Du, F. 2013. Levels, composition profiles and sources of polycyclic aromatic hydrocarbons in surface sediments from Nan'ao Island, a representative mariculture base in south China. Mar. Poll. Bull. 75: 310-316.

Guo, W., He, M.C., Yang, Z.F., Lin, C.Y., Quan, X.C. \& Wang, H.Z. 2007. Distribution of polycyclic aromatic hydrocarbons in water, suspended particulate matter and sediment from Daliao river watershed, China. Chemosph. 68: 93-104.

Harrison, R.M., Smith, D.J.T., Pio, C.A. \& Castro, L.M. 1996. Source apportionment of atmospheric polycyclic aromatic hydrocarbons collected from an urban location in Birmingham, UK. Environ. Sci. Tech. 30(3): 825-832.

Hopke, P.K. 2003. Recent developments in receptor modeling. J. Chemom. 17: 255-265.

Hosseini, M., Peery, S., Bastami, O.K.A.A. \& Monikh, F.A. 2012. Distribution of polycyclic aromatic hydrocarbons in water (Persian Gulf) (Iran). American-Eurasian J. Toxic Sci. 4(2): 94-97.

IARC 1983. Polynuclear aromatic compounds, Part 1, chemical, environmental and experimental data. IARC Monogr. Eval. Carcinog. Risk Chem. Hum. 32: 1-453. 
Jamhari, A.A., Sahani, M., Latif, M.T., Chan, K.M., Tan, H.S., Khan, M.F. \& Tahir, N.M. 2014. Concentration and source identification of polycyclic aromatic hydrocarbons (PAHs) in PM10 of urban, industrial and semi-urban areas in Malaysia. Atmos. Env. 86: 16-27.

Jiang, Y.F., Wang, X.T., Wang, F., Jia, Y., Wu, M.H., Sheng, G.Y. $\& \mathrm{Fu}$, J.M. 2009. Levels, composition profiles and sources of polycyclic aromatic hydrocarbons in urban soil of Shanghai, China. Chemos. 75(8): 1112-1118.

Karickhoff, S.W. 1984. Organic pollutant sorption in aquatic systems. J. Hydra. Eng. 110: 707-735.

Khairy, M.A., Kolb,M., Mostafa,A.R.,EL-Fiky,A. \& Bahadir,M. 2009. Risk assessment of polycyclic aromatic hydrocarbons in a Mediterranean semi-enclosed basin affected by human activities (Abu Qir Bay, Egypt). J. Hazard Mater. 170: 389397.

Khan, M.F., Hirano, K. \& Masunaga, S. 2010. Quantifying the sources of hazardous elements of suspended particulate matter aerosol collected in Yokohoma, Japan. Atm. Environ. 44: 2646-2657.

Khim, J.S., Kannan, K., Villeneuve, D.L., Koh, C.H. \& Giesy, J.P. 1999. Characterization and distribution of trace organic contaminants in sediment from Masan Bay, Korea. Environ. Sci.Tech. 33: 4199-4205.

Klanova, J., Matykiewiczova, N., Macka, Z., Prosek, P., Laska, K. \& Klan, P. 2007. Persistent organic pollutants in soils and sediments from James Ross Island, Antartica. Environ. Poll. 8: 1-8.

Ko, F., Chang, C. \& Cheng, J. 2014. Comparative study of PAHs in coral tissues and the ambient sediments from Kenting National Park, Taiwan. Environ. Poll. 185: 35-43.

Kucuksezgin, F., Pazi, I. \& Gohul, L.T. 2012. Marine organic pollutants of the Eastern Aegean: Aliphatic and polycyclic aromatic hydrocarbons in Candarli gulf surficial sediments. Mar. Poll. Bull. 64: 2569-2575.

LADA. 2011. Langkawi Development Authority Report. http:// www.lada.gov.my/v2/en/.

Liu, Y., Chen, L., Huang, Q., Li, W. \& Tang, Y. 2009. Source apportionment of polycyclic aromatic hydrocarbons (PAHs) in surface sediments of the Huangpu River, Shanghai, China. Sci. Total Environ. 407: 2931-2938.

Luo, X.S., Yu, S., Zhu, Y.G. \& Li, X.D. 2011. Trace metal contamination in urban soils of China. Sci. Total Environ. 421-422: $17-30$

Marr, L.C., Kirchstetter, T.W., Harley, R.A., Miguel, A.H., Hering, S.V. \& Hammond, S.K. 1999. Characterization of polycyclic aromatic hydrocarbons in motor vehicle fuels and exhaust emissions. Environ. Sci. Tech. 33: 3091-3099.

Mostafa, A.R., Wade, T.L., Sweet, S.T., Al-Alimi, A.K.A. \& Barakat, A.O. 2009. Distribution and characteristics of polycyclic aromatic hydrocarbons (PAHs) in sediments of Hadhramout coastal area, Gulf of Aden, Yemen. J. Mar. Sys. 78: 1-8.

Motelay-Massei, A., Ollivon, D., Garban, B., Tiphagne-Larcher, K., Zimmerlin, I. \& Chevreuil, M. 2007. PAHs in the bulk atmospheric deposition of the Seine River basin: Source identification and apportionment by ratios, multivariate statistical techniques and scanning electron microscopy. Chemosphere 67: 312-321.

Murakami, M., Nakajima, F. \& Furumai, H. 2005. Size-and density distributions and sources of polycyclic aromatic hydrocarbons in urban road dust. Chemosphere 61: 783-791.
Nasher, E., Lee, Y.H., Zakaria, Z. \& Surif, S. 2013. Assessing the ecological risk of polycyclic aromatic hydrocarbons in sediments at Langkawi Island, Malaysia. The Sci. World J. 2013: Article ID. 858309.

Thurston, G.D. \& Spengler, J.D. 1985. A quantitative assessment of source contribution to inhalable particulate matter pollution in metropolitan Boston. Atm. Environ. 19: 9-25.

Thurston, G.D., Ito, K. \& Lall, R. 2011. A source apportionment of U.S. fine particulate matter air pollution. Atm. Environ. 45: 3924-3936.

Osman, R., Saim, N., Juahir, H. \& Abdullah, M.P. 2012 Chemometric application in identifying sources of organic contaminants in Langat river basin. Environ. Monit. Assess. 184(2): 1001-1014.

Page, D.S., Boehm, P.D., Douglas, G.S., Bence, A.E., Burns, W.A. \& Mankiewicz, P.J. 1999. Pyrogenic polycyclic aromatic hydrocarbons in sediments record past human activity: A case study in Prince William sound, Alaska. Mar. Poll. Bull. 38: $247-260$.

Park, S.U., Kim, J.G., Jeong, M.J. \& Song, B.J. 2011. Source identification of atmo-spheric polycyclic aromatic hydrocarbons in industrial complex using diagnostic ratios and multivariate factor analysis. Environ. Contam. Toxico. 60: 567-589.

Pierson, W.L., Bishop, K., Van, S., Horton, P.R. \& Adamantis, C.A. 2002. Environmental water requirements to maintain estuarine processes. Env. Flows in Tech. Rep. Report no. 3 Commonwealth of Australia.

Prahl, F.G. \& Carpenter, R. 1983. Polycyclic aromatic hydrocarbons (PAH)-phase associations in Washington coastal sediment. Geochim. Cosmochim. Acta 47: 1013-1023.

Riccardi, C., Filippo, P., Pomata, D., Basilio, M.\& Spicaglia, S 2013. Identification of hydrocarbon sources in contaminated soils of three industrial areas. Sci. Total Environ.450: 13-21.

Pietzsch, R.,Patchineelam, S.R. \& Torres, J.P.M. 2010. Polycyclic aromatic hydrocarbons in recent sediments from a subtropical estuary in Brazil. Mar. Chem. 118(1-2): 56-66.

Samat, N. 2010. Assessing land use land cover changes in Langkawi Island: Towards sustainable urban living. Malaysian J. Environ. Management 11(1): 48-57.

Sanders, M., Sivetsen, S. \& Scott, G. 2002. Origin and distribution of polycyclic aromatic hydrocarbons in surficial sediments from the Savannah River. Archi. Environ. Contam. Toxicol. 43: 438-448.

Sicre, M.A., Marty, J.C., Saliot, A., Aparicio, X., Grimalt, J. \& Albaiges, J. 1987. Aliphatic and aromatic hydrocarbons in different sized aerosols over the Mediterranean Sea: Occurrence and origin. Atm. Environ. 21: 2247-2259.

Simenov, V., Stratis, J.A., Samara, C., Zachariadas, G., Voutsa, D., Anthemidis, A., Sofoniou, M. \& Kouimtzis, T. 2002. Assessment of the surface water quality in northern Greece. Wat. Res. 37: 4119-4124.

Soclo, H., Garrigues, P.H. \& Ewald, M. 2000. Origin of polycyclic aromatic hydrocarbons (PAHs) in coastal marine sediments: Case studies in Cotonou (Benin) and Aquitaine (France) areas. Mar. Poll. Bull. 40: 387-396.

Saha, M., Togo, A., Mizukawa, K., Murakami, M. \& Takada, H 2009. Sources of sedimentary PAHs in tropical Asian waters: Differentiation between pyrogenic and petrogenic sources by alkyl homolog abundance. Mar. Poll. Bull. 58: 189-200.

Sverdrup, L.E., Nielsen, T. \& Krogh, P.H. 2002. Soil ecotoxicity of polycyclic aromatic hydrocarbons in relation to soil sorption, lipophilicity and water solubility. Environ. Sci. Tech. 36: 2429-2435. 
Tam, N.F.Y., Ke, L., Wang, X.H. \& Wong, Y.S. 2001. Contamination of polycyclic aromatic hydrocarbons in surface sediment of mangrove swamps. Environ. Poll. 114: 225-263.

Vaezzadeh, V., Zakaria, M.P., Mustafa, S., Ibrahim, Z.Z. \& Shau-Hwai, A.T. 2014. Distribution of polycyclic aromatic hydrocarbons (PAHs) in sediment from Muar River and Pulau Merambong, Peninsular Malaysia. Proceedings Int. Con. Environ. Forensics 8:451-455.

Wang, G.,Zhang, Q., Ma, P., Rowden, J., Mielke, H.W., Gonzales, C. \& Powell,E. 2009. Sources and distribution of polycyclic aromatic hydrocarbons in urban soils: Case studies of Detroit and New Orleans. Soil Sediment Contam. 17: 547-563.

Ying, L., Chen, L., Jianfu, Z., Qinghui, H., Zhiliang, Z. \& Hongwen, G. 2008. Distribution and sources of polycyclic aromatic hydrocarbons in surface sediments of rivers and an estuary in Shanghai, China. Environ. Poll. 154: 298-305.

Yunker, M.B., MacDonald, R.W., Vingarzanc, R., Mitchelld, R.H., Goyettee, D. \& Sylvestre, S. 2002. PAHs in the Fraser river basin: A critical appraisal of PAH ratios as indicators of PAH source and composition. Org. Geochem. 33: 489-515.

Zakaria, M.P., Okuda, T. \& Takada, H. 2001 . Polycyclic aromatic hydrocarbon (PAHs) and hopanes in stranded tar-balls on the coasts of peninsular Malaysia: Applications of biomarkers for identifying sources of oil pollution. Mar. Poll. Bull. 42: 1357-1366.

Zakaria, M.P., Takada, H., Tsutsumi, S., Ohno, K., Yamada, J., Kouno, E. \& Kumata, H. 2002. Distribution of polycyclic aromatic hydrocarbons (PAHs) in rivers and estuaries in Malaysia: A widespread input of petrogenic PAHs. Environ. Sci.Tech. 36: 1907-1918.

Zhang, Y., Guo, C.S., Xu, J., Tian, Y.Z., Shi, G.L. \& Feng, Y.C. 2012. Potential source contributions and risk assessment of PAHs in sediments from Taihu Lake, China: comparison of three receptor models. Water Resources 46: 3065-3073.

Terence Ricky Chiu, Mohd Talib Latif,

Mohd Shahrul Mohd Nadzir, Haris Hafizal Abdul Hamid,

Hafidz Yusoff \& Masni Mohd Ali*

Faculty of Science and Technology

Universiti Kebangsaan Malaysia

43600 UKM Bangi, Selangor Darul Ehsan

Malaysia
Md Firoz Khan, Mohd Talib Latif \& Mohd Shahrul Mohd Nadzir Research Centre for Tropical Climate Change System Institute of Climate Change

Universiti Kebangsaan Malaysia

43600 UKM Bangi, Selangor Darul Ehsan

Malaysia

Masni Mohd Ali*

Institute of Oceanography and Environment

Universiti Malaysia Terengganu

21030 Kuala Nerus, Terengganu Darul Iman

Malaysia

*Corresponding author; email: masni@ukm.edu.my

Received: 15 September 2017

Accepted: 13 December 2017 